\title{
Моніторинг популяцій раритетних видів судинних рослин Черемського природного заповідника (Західне Полісся, Україна)
}

\section{Іван Данилик', Світлана Сосновська', Олександр Кузярін ${ }^{2}$, Ірина Кузьмішина Лариса Коцун ${ }^{3}$}

${ }^{1}$ Інститут екології Карпат НАН України, м. Львів, Україна

${ }^{2}$ Державний природознавчий музей НАН України, м. Львів, Україна

${ }^{3}$ Східноєвропейський національний університет імені Лесі Українки, м. Луцьк, Україна

Адреса для листування: idanylyk@ukr.net

Отримано: 06.10.18; прийнято до друку: 12.11.18; опубліковано: 26.12.18

Резюме. Наведено результати оцінки стану популяцій восьми раритетних видів судинних рослин із різними рівнями охорони (міжнародним, національним і регіональним) для території водно-болотного флороценокомплексу Черемського природного заповідника. Серед них два види - (Hammarbya paludosa (L.) O. Kuntze та Dactylorhiza incarnata (L.) Soó) - уключено до Додатка II CITES. Шість видів - (Carex chordorrhiza Ehrh., D. incarnata, H. paludosa, Salix lapponum L., Scheuchzeria palustris L., Utricularia intermedia Hayne) - перебувають під охороною Червоної книги України; два - (Carex limosa L., Drosera rotundifolia L.) - регіонально рідкісні для Волинської області. На популяціях модельних видів рослин проведено апробацію інформативності диференційних й інтегральних ознак популяцій, які доцільно обрати за критерії визначення їх стану в процесі проведення моніторингових досліджень. Площа популяції D. rotundifolia охоплює практично все болото, проективне покриття виду становить до $5 \%$. Популяція C. limosa є процвітаючою, жодних додаткових заходів зі збереження не потребує. Відзначено високий адаптивний потенціал $C$. chordorrhiza, що дає змогу виду досить ефективно поширюватися на різні ділянки болотного масиву, відмінні за ступенем трофності. На досліджуваній території S. palustris відзначається доволі високою частотою трапляння, його проективне покриття подекуди досягає 10-15\%. На мезотрофних ділянках Черемського болота, у мочажинах й у вікнах серед різнотрав'я U. intermedia формує невеличкі популяційні локуси, площа яких здебільшого не перевищує $0,25 \mathrm{~cm}^{2}$. На площі близько $50 \mathrm{~m}^{2}$ виявлено виключно молоді особини S. lapponum, поширені розсіяно-дифузно на віддалі 2-3 м одне від одного. Популяційний локус $\boldsymbol{H}$. paludosa займає невелику площу $16 \mathrm{~m}^{2}$ у складі мезооліготрофного рослинного комплексу з переважанням дрібних осок та щільного сфагнового покриття. Генеративні особини виду мають низький та середній рівні життєвості. D. incarnata на території масиву поширена доволі спорадично - площа популяції досягає $5000 \mathrm{~m}^{2}$ із розсіяно-дифузним просторовим розміщенням. Узагальнено отримані результати й розроблено практичні рекомендації щодо застосування пропонованих методик дослідження вибраних критеріїв стану популяцій раритетних видів рослин під час їх моніторингу на території Черемського природного заповідника, що є основою науково обгрунтованих критеріїв созологічного менеджменту.

Ключові слова: рідкісні судинні рослини, морфопараметри, популяція, моніторинг, созологічний менеджмент, Черемський природний заповідник.

\section{Monitoring of Rare Vascular Plant Populations in Cheremskyi Nature Reserve (Volyn Region, Ukraine)}

\section{Ivan Danylyk ${ }^{1}$ Svitlana Sosnovska ${ }^{1}$, Oleksandr Kuzyarin ${ }^{2}$, Iryna Kuzmishyna ${ }^{3}$, Larysa Kotsun ${ }^{3}$}

${ }^{1}$ Institute of Ecology of the Carpathians NAS of Ukraine, Lviv, Ukraine

${ }^{2}$ State Natural History Museum of the NAS of Ukraine, Lviv, Ukraine

${ }^{3}$ Lesya Ukrainka Eastern European National University, Lutsk, Ukraine

Correspondence: idanylyk@ukr.net 
Abstract. The results of the inventory of the populations status of rare vascular plants with different levels of protection (international, national and regional) in the wetland area of Cheremskyi Nature Reserve have been established. Among them two species (Dactylorhiza incarnata (L.) Soó and Hammarbya paludosa (L.) O. Kuntzeand) are listed for Addition II CITES. Six species (Carex chordorrhiza Ehrh., D. incarnata, H. paludosa, Salix lapponum L., Scheuchzeria palustris L., Utricularia intermedia Hayne) are protected according to the Red Data Book of Ukraine (2009). Two species (Carex limosa L. and Drosera rotundifolia L.) are regionally rare for the Volyn region. The populations of model plant species have been assessed by structural and functional parameters, which it is advisable to choose as the criteria for determination of their condition in the process of conducting monitoring research. The population of $D$. rotundifolia covers almost the entire bog, the projective cover of the species is up to $5 \%$. The population of C. limosa is thriving and does not need any additional conservation measures. A high adaptive potential of C. chordorrhiza was noted, which allows the species to spread quite effectively to different parts of the bog massif, which differ by the degree of trophicity. In the investigated territory S. palustris is noted by a rather high-frequency of occurrence, its projective cover in some places reaches $10 \%$. In the mesotrophic areas of the Cheremske bog, in hollows, $U$. intermedia forms small population loci, the area of which for the most part does not exceed $0,25 \mathrm{~cm}^{2}$. On an area of about $50 \mathrm{~m}^{2}$, only young individuals of $S$. lapponum were found, spreading diffusely at a distance of 2-3 $\mathrm{m}$ from each other. The H. paludosa population locus occupies a small area of $16 \mathrm{~m}^{2}$ in the community of a meso-oligotrophic plant complex with a predominance of small sedges and a dense sphagnum cover. The generative individuals of the species have a medium and low level of vitality. D. incarnata in the territory of the bog is rather sporadic - the population area reaches $5000 \mathrm{~m}^{2}$ with a sparsely-diffuse spatial location. The obtained results are summarized and practical recommendations are developed regarding the application of the proposed methodologies for the study of selected criteria for the status of the rare species populations during their monitoring on the territory of the Cheremskyi Nature Reserve, which is the basis of the science-based criteria for the sozological management.

Key words: rare vascular plants, morphological parameters, population, monitoring, sozological management, Cheremskyi Natural Reserve.

\section{Вступ}

Обгрунтування ефективних природоохоронних заходів стосовно раритетних видів рослин та їх подальше впровадження в практику - невід'ємна складова частина сучасної парадигми збереження біорізноманіття, що грунтується на даних комплексних біогеографічних, екологоценотичних, популяційних досліджень і бере офіційний початок із Конференції ООН (Ріо-деЖанейро, 1992). Багаторічний досвід як вітчизняних, так і закордонних колег у галузі фітосозології свідчить про те, що найнадійнішою формоюереження фітогенофонду й фітоценофонду $є$ їх охорона in situ в природних умовах заповідних територій. Проте станом на сьогодні ще й досі остаточно не розроблено чимало теоретичних i практичних питань заповідної справи. В Україні відсутній комплексний підхід до проблеми охорони та відновлення фіторізноманіття як цілісної системи, що повинен грунтуватися, передусім, на результатах наукового моніторингу (Andriyenko, 2006).

Моніторинг популяцій рослин, що перебувають під охороною 3 тих чи інших причин або поточний стан і перспективи яких викликають певні занепокоєння, $\epsilon$ обов'язковою процедурою для виконання низки першочергових теоретичних та практичних природоохоронних завдань. Проте $в$ цьому аспекті потребують узагальнення й обгрунтування відповідні критерії, методики та підходи щодо його реалізації на природоохоронних територіях. Одним із першочергових завдань $є$ підбір найбільш інформативних параметрів моніторингу із залученням неушкоджувальних методик, що дасть змогу мінімізувати негативний вплив на рідкісні види рослин, оцінити їх охоронний статус, 3'ясувати причини, які зумовлюють зменшення їх чисельності. У цьому контексті на особливу увагу заслуговує популяційний аспект, адже саме популяції належить важливе місце в системі біотичного різноманіття як структурному елементі виду й компонента екосистеми (Golubets, 2000). Комплексне дослідження структурно-функціональної організації популяцій видів - невід'ємна складова частина фітомоніторингу та безпосередньо пов'язана зі встановленням диференційних індивідуальних й інтегральних параметрів як інформативних критеріїв оцінки ï стану (Tsaryk, J., Tsaryk, I., 2008; Perzanowska, 2010 та ін.). Для існування популяцій першочергове значення мають такі інтегральні показники, як чисельність і щільність особин виду, площа популяції; іiі вікова, просторова, статева й віталітетна структура; до диференційних індивідуальних параметрів належать ознаки особин, такі як габітус, віковий стан, характер онтогенезу, параметри репродуктивних процесів та морфологічна мінливість (Malynovskyj, 1998). 
Поряд із загальноприйнятими критеріями рідкісності видів (хорологічний, ценотичний тощо) грунтовно проведений популяційний аналіз дає можливість повною мірою здійснити ïх адекватну созологічну оцінку, установити динамічні тенденції й характер виявлених змін (прогресивні чи регресивні), спрогнозувати їх перспективи, а тому є хорошим підгрунтям для оптимізації інформаційних та організаційних засад природоохоронного менеджменту.

\section{Мета, матеріали та методи}

Відповідно до зазначеної вище наукової проблеми метою досліджень було покращення інформаційних й організаційних засад збереження раритетного фітогенофонду Черемського природного заповідника (ПЗ) за допомогою оцінки популяційних параметрів та ефективності їх використання в аспекті збереження раритетних видів рослин. Об'єктами дослідження слугували популяції рідкісних і зникаючих видів судинних рослин особливо цінного природного комплексу Черемського ПЗ - Черемського болота. У роботі використало загальноприйняті методи популяційної екології рослин, фітосоціологічні та статистичні методи.

Черемський природний заповідник (ПЗ) створено в грудні 2001 р. на основі ботанічного заказника загальнодержавного значення Черемський площею 908 га, а також трьох заказників місцевого значення, зокрема орнітологічного заказника Урочище Сузанка, загальнозоологічного Карасинський i ботанічного заказника Карасинський ялинник-1 (Karpyuk et al., 2018). На сьогодні загальна площа заповідника становить 2975,7 га (Litopys..., 2017). Це перший заповідник у Волинській області та один із найбільш північних в Україні. Раритетну флористичну компоненту Черемського (ПЗ) вивчали Т. Л. Андрієнко зі співавторами (Andriyenko, 1975; Andriyenko, Pryadko, 1980; Andriyenko, 2006), В. В. Коніщук (Konishhuk, 2003), Л. О. Коцун зі співавторами (Koczun et al., 2006) та ін.

Черемський ПЗ розміщений на території північної частини Маневицького району Волинської області в західній частині Поліської низовини на межі Верхньоприп'ятської долини та Волинського моренного пасма. Його малопорушені антропогенною діяльністю природно-територіальні комплекси представлені тут суцільними лісовими масивами 3 унікальним еумезотрофним осоково-сфагновим
Черемським болотом, що $\epsilon$ своєрідним нагромаджувальним резервуаром води із помірним стоком. На території водноболотного комплексу розміщені два озера (у центрі болота - Черемське (місцева назва Чірмуське), на сході - Редичі), система осушувально-зволожувальних каналів i струмків, низка болотних островів. Через північно-східну частину Черемського болота проходить слабко виражена лінія вододілу річок Стохід та Веселуха. Загалом водні екосистеми займають $34,6 \%$ території. За геоботанічним районуванням України територія Черемського ПЗ належить до Верхньоприп'ятського округу соснових, вільхових, ялинових (фрагментарно) лісів, заплавних лук й евтрофних боліт Поліської підпровінції хвойно-широколистяних лісів (Didukh, Sheliah-Sosonko, 2003).

Територія Черемського ПЗ є повністю заповідною зоною, яка створена 3 метою довічного збереження екосистем в абсолютно заповідному та регульовано заповідному режимах. Абсолютно заповідний режим застосовують до екосистем, що не потребують утручання та самостійно розвиваються в недоторканому стані.

\section{Результати}

Задля визначення популяційних параметрів моніторингу раритетного фітогенофонду Черемського болота обрано популяції восьми модельних видів рослин моно- та поліцентричного типів біоморфи (табл. 1). Із них шість перебувають під охороною Червоної книги України (Didukh, 2009): Carex chordorrhiza Ehrh., Dactylorhiza incarnata (L.) Soó s.l., Hammarbya paludosa (L.) O. Kuntze, Salix lapponum L., Scheuchzeria palustris L., Utricularia intermedia Hayne., два види належать до списку регіонально рідкісних видів, що охороняються у Волинській області (Andriyenko, Peregrym, 2012): Carex limosa L., Drosera rotundifolia L. H. paludosa занесено до Додатка II CITES (Didukh, 2009, s. 186).

Одним із регіонально-рідкісних видів Черемського болотного комплексу є Drosera rotundifolia L. (Droseraceae) - голарктичний бореальний вид, багаторічна трав'яна комахоїдна рослина, розетковий гемікриптофіт, олігомезотроф, гігрофіт, геліофіт. Площа популяції охоплює практично все болото. Проективне покриття виду становить до $5 \%$. Щільність коливається від 16 особин $/ \mathrm{m}^{2}$ на оліготрофних ділянках до 52 особин на м² на 
Науковий вісник Східноєвропейського національного університету імені Лесі Українки. Серія: Біологічні науки, 2018, 8 (381)

Таблиия 1

\section{Біоморфологічна характеристика рідкісних модельних видів рослин на території Черемського Водно-болотного комплексу}

\begin{tabular}{|c|c|}
\hline Тип біоморфи & Вид рослин \\
\hline Моноцентричний & $\begin{array}{c}\text { Dactylorhiza incarnata, Drosera rotundifolia, Hammarbya paludosa, Salix } \\
\text { lapponum }\end{array}$ \\
\hline Поліцентричний & Carex chordorrhiza, C. limosa, Scheuchzeria palustris, Utricularia intermedia \\
\hline
\end{tabular}

мезотрофних та мезооліготрофних (середній показник - 22,0 $\pm 0,3$ особини на $\mathrm{m}^{2}$ ). Просторова структура ценопопуляцій групова, місцями - компактно-дифузна. Найбільшої щільності особини досягають у центральній частині болотного масиву через те, що подекуди по периферії активне поширення виду блокують більш конкуретоспроможні рослини, зокрема Phragmites australis (Cov.) Trin. ex Steud. та осокові (Carex rostrata Stokes, Eriophorum vaginatum L.). У складі популяції переважають особини із середніми значеннями морфопараметрів - висота генеративного пагона становила $23,1 \pm 0,5 \mathrm{~cm}$, а мінімальний та максимальний показники коливалися в межах 17,5 і 30 см відповідно. Вікова структура повночленна 3 переважанням іматурної та віргінільної вікових груп $(48 \%)$. Частка генеративних особин досягала $35 \%$. Популяція існує за сприятливих еколого-ценотичних умов та ефективно відтворюється. Найбільш інформативними моніторинговими параметрами цього виду є чисельність і щільність особин (як генеративних, так і вегетативних), розмірна диференціація генеративних особин за класами віталітету 3 використанням таких індикаційних показників, як висота генеративного пагона, кількість листків, а також віковий спектр популяції.

Іншим регіонально-рідкісним видом Черемського ПЗ є голарктичний бореальний вид Carex limosa L. (Cyperaceae), багаторічна трав'яна рослина, гемікриптофіт, гігрофіт, мезооліготроф, геліофіт. Найчастіше трапляється на мезооліготрофних ділянках болота в угрупованнях зі Sphagnum girgensohnii Russow (5), Polytrichastrum longisetum (Sw.ex Brid.) G.L.Sm. (1), Dicranum polysetum Sw. (+), Oxycoccus palustrisPers. (2b), Menyanthes trifoliata L. (2a), Phragmites australis (1), Naumburgia thyrsiflora (L.) Reichenb. (1), Scheuchzeria palustris (+), Lysimachia vulgaris L. $(+)$, Drosera rotundifolia (+), Eriophorum vaginatum (+), Thelypteris palustris Schott (+), Juncus effusus L. (+), Rhynchospora alba (L.) Vahl (+), Carex lasiocarpa Ehrh. (+), C. canescens
L. (+), Salix cinerea L. (+), Pinus sylvestris L. (+), Betula pendula Roth (+), B. pubescens Ehrh. (+). Проективне покриття C. limosa коливається в межах 10-25\%. Щільність становить $8,3 \pm 0,2$ генеративних пагонів на $\mathrm{M}^{2}$, поширених дифузно. Вікова структура 3 лівостороннім віковим спектром, а співвідношення генеративних пагонів до вегетативних становить 1:7, розмножується здебільшого вегетативно. У популяції присутнє також насіннєве поновлення, зокрема частка зав'язаних мішечків у колосках досягає $90 \%$. Особини популяції відзначаються високою життєвістю, середнє значення висоти пагона під час обстежень становило $39,0 \mathrm{~cm} \pm 1,1$ (при зафіксованому максимальному показнику 45 см). Загалом популяція C. limosa $\epsilon$ процвітаючою, жодних додаткових заходів зі збереження не потребує (рис. 1). 3 огляду на морфолого-біологічні особливості виду, а саме поліцентричний тип біоморфи, під час проведення регулярного моніторингу доцільно здійснювати облік таких показників, як щільність генеративних і вегетативних пагонів (рамет), ïx співвідношення. При цьому підрахунок вегетативних пагонів доцільно виконувати в межах трансекти на малих дослідних площадках $(20$ х 20 см); тип просторової структури та тї зміни (із можливим картуванням у межах трансекти); віталітетна структура на основі вимірювань висоти генеративного пагона, довжини листка, кількості колосків. Carex chordorrhiza Ehrh. (Cуреraceae) - голарктичний бореальний вид, гляціальний релікт із природоохоронним статусом вразливий (Didukh, 2009, s. 85) та сучасними тенденціями до скорочення свого ареалу, багаторічна трав'яна рослина, гемікриптофіт, гігрофіт, мезотроф, геліофіт. Завдяки високій вегетативній рухливості й значним приростам столонів активно колонізує оптимальний екотоп. Потрібно відзначити, що на Черемському болоті ця осока поширена доволі дифузно, а щільність генеративних пагонів не перевищуе 12 одиниць на $\mathrm{m}^{2}$. Показник доволі незначний, проте детальний 


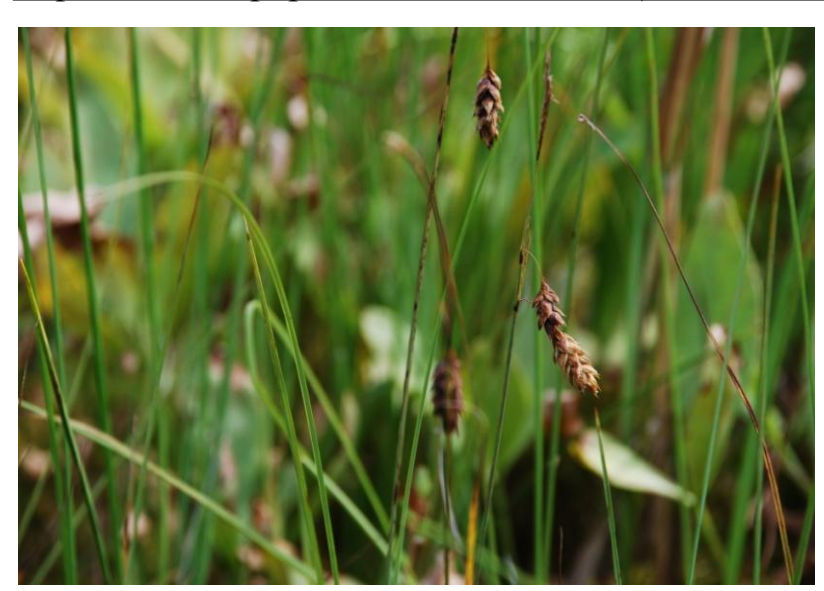

Рис. 1. Регіонально-рідкісний вид

Черемського природного заповідника Сагех limosa (фото I. М. Данилика)

підрахунок на малих ділянках $\left(20 \times 20 \mathrm{~cm}^{2}\right)$ засвідчив, що в складі ценопопуляції істотно переважають вегетативні пагони у співвідношенні $1: 12$. Так, їх щільність на $\mathrm{m}^{2}$ досягала місцями до 140 пагонів. Вікова структура ценопопуляції 3 характерним лівостороннім спектром (понад $60 \%$ становлять прегенеративні пагони) та незначною часткою репродуктивних пагонів (10-15\%). Статева структура типова, із переважанням жіночих квіток у колосках. Ефективність насіннєвого поновлення невисока, проте ценопопуляція успішно самопідтримується вегетативно. Проведено також вимірювання морфометричних параметрів особин; iз них найбільш інформативним виявися показник висоти генеративного пагона, що істотно змінювався залежно від умов росту в діапазоні від 18,0 до 31,7 см (середнє значення - 26,1 $\pm 2,1 \mathrm{~cm}$ ). У дослідженій локальній популяції переважали особини із середніми значеннями цього морфопараметра. Варто зазначити, що впродовж досліджень нами виявлено значну морфологічну мінливість та відзначено високий адаптивний потенціал цього виду, що дає змогу C. chordorrhiza досить ефективно поширюватися на різні за ступенем трофності ділянки болотного масиву. Так, цей вид нами виявлено в складі прибережно-водної рослинності озера Черемське серед високих осок і Phragmites australis. Особливості екотопу зумовлюють формування специфічної водної життєвої форми виду. У прибережних особин C. chordorrhiza формуються потужні вегетативні пагони, їх довжина та ширина майже удвічі перевищує показники в представників типових мезотрофних i мезооліготрофних місцезростань. Колоски в таких рослин не формуються, тому їх поновлення відбувається виключно вегетативно. На таких окраїнних прибережних ділянках C. chordorrhiza трапляється спорадично, що пояснюється умовами росту, які $є$ далекими від оптимуму, та й порівняно нижчою конкурентоспроможністю цього виду, порівняно $з$ типовими гідро- та гігрофітами. Усе ж загалом стан виявлених локальних ценопопуляцій $C$. chordorrhiza $є$ задовільним. Їх стабільність та життєвий статус у подальшому значною мірою залежатиме від мінливості еколого-ценотичних умов (зміни гідрорежиму, заростання ділянок болота) i режиму збереження.

Scheuchzeria palustris L. (Scheuchzeriaceae) голарктичний бореальний вид на південній межі поширення, що скорочує свій ареал, 3 охоронним статусом вразливий (Didukh, 2009, s. 268), багаторічна трав'яна рослина, кореневищний геофіт, гігрофіт, мезооліготроф, геліофіт. На території Черемського болота відзначається доволі високою частотою трапляння, його проективне покриття подекуди досягає $15 \%$ (рис. 2). Найбільшу щільність мають локальні ценопопуляції, приурочені до відкритих оліготрофних і мезооліготрофних ділянок; середній показник становить $9,3 \pm 0,2$ генеративних пагонів. Просторова структура переважно дифузного типу. Проведені обрахунки на ділянках $20 \times 20 \mathrm{~cm}^{2}$ указують на кількісне переважання вегетативних пагонів; їх щільність досягала 11,6 на $1 \mathrm{~m}^{2}$. Віталітетну структуру популяції формують особини середньої й низької життєвості; висота генеративного пагона коливалась у межах від 15,5 до 20,5 см (середнє значення $18,4 \pm 0,8$ см). Рослини активно плодоносили: на одному генеративному пагоні нараховано 2-5 суплідь, кожне 3 яких складається 3 3-5 плодиків із 1-2 насінинами. Коефіцієнт обнасінення досягав $80 \%$. Незважаючи на високий потенціал до насіннєвого поновлення, самопідтримання популяції відбувається переважно вегетативно, завдяки значним приростам кореневищ, а відтак високій колонізаційній здатності. Стан популяції констатуємо як задовільний. До індикаційних параметрів, які можуть бути застосовані для проведення моніторингу за станом популяції S.palustris, зараховуємо шільність генеративних i вегетативних пагонів, їx співвідношення у віковому спектрі; оцінку віталітету за показниками висоти генеративного пагона, довжини суцвіття та 
кількості квіток); насінневу продуктивність. Для дослідження вегетативної рухливості доцільно також здійснювати облік річних приростів кореневищ.

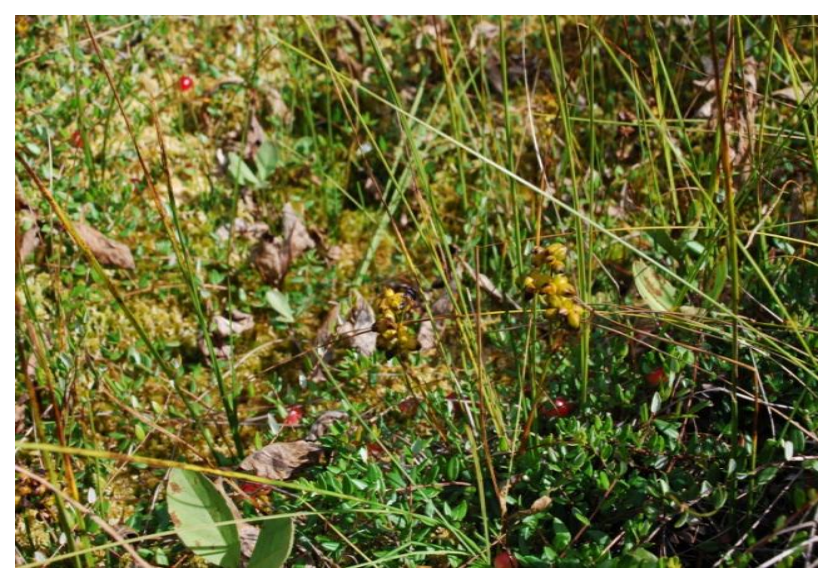

Рис. 2. Scheuchzeria palustris y вiдкритих ділянках Черемського болота (фото I. М. Данилика)

На мезотрофних ділянках Черемського болота, у мочажинах-калюжах спорадично траплялась Utricularia intermedia Hayne (Lentibulariaceae) - циркумполярний вид, що скорочує своє поширення, 3 охоронним статусом вразливий (Didukh, 2009, s. 515), водна комахоїдна багаторічна трав'яна рослина, плейстофіт, гідрофіт, олігомезотроф, сциогеліофіт. Цей вид на дослідженій території формує невеличкі локуси, площа яких здебільшого не перевищує $0,25 \mathrm{~cm}^{2}$. За дослідженнями 2017 р. зафіксовано дуже незначну частку квітучих особин (менше $5 \%$ ), здебільшого траплялися вегетативні клони, котрі рівномірно вкривали площу болотних калюж. Стан досліджених ценопопуляцій на території Черемського болота також є задовільним. 3 огляду на невисоку частоту трапляння виду й малу частку репродуктивних особин $U$. Intermedia потребує регулярного моніторингу. Найбільш інформативними показниками для оцінки стану популяцій $\epsilon$ чисельність і щільність генеративних пагонів у межах окремих популяційних локусів (мочажинкалюж), оскільки підрахунок вегетативних $\epsilon$ доволі ускладненим як життєвою формою виду, так і умовами росту. У випадку наявності вибірки генеративних пагонів важливими є такі морфометричні показники, як їх висота й кількість квіток, які в подальшому будуть використані для оцінки життєвості популяцій.

На особливу увагу серед видів болотного комплексу заслуговують нанофанерофіти, до яких належать карликові верби. Серед них одним із найбільш раритетних представників $є$ Salix lapponum L. (Salicaceae) - бореальний євросибірський реліктовий вид на південній межі поширення, 3 охоронним статусом вразливий (Didukh, 2009, s. 585), кущ, гігрофіт, мезотроф, геліофіт. Зазначений вид трапляється на мезотрофній ділянці болота в угрупованні 3 Salix aurita L. (+), S. cinerea L. (+), S. rosmarinifolia L. (+), Betula pendula Roth. $(+)$, B. pubescens Ehrh. (+), Calamagrostis canescens (Web.) Roth(+), Phragmites australis (2), Peucedanum palustre (L.) Moench (1), Rhynchospora alba (L.) Vahl (1), Typha latifolia L. (+), Carex rostrata Stokes(+), Comarum palustre L. (2), Lysimachia vulgaris L. (2), Naumburgia thyrsiflora (L.) Reichenb. (1), Menyanthes trifoliata L. (2), Lythrum salicaria L. (1), Epilobium palustre L. (+), Sphagnum spp. (5). Популяційний локус займає площу близько $50 \mathrm{~m}^{2}$, де представлені лише молоді (віргінільні) особини - невеличкі кущі до 1,5 м заввишки. На вказаній ділянці було до восьми особин, розміщених розсіяно-дифузно на віддалі 2-3 м одна від одної. Вочевидь, площа популяції $€$ значно більшою, поновлення популяції нормальне. Із метою оцінки стану популяції цього виду доцільно провести масштабне обстеження території та визначити чіткі контури окремих ценопопуляцій. Розмір трансекти в цьому випадку доцільно обирати не менше ніж $25 \mathrm{~m}^{2}$ залежно від характеру просторового розташування особин (дифузне, групове тощо). Інформативними будуть показники щільності та чисельності особин на цій площі, співвідношення молодих i генеративних особин, кількість сформованих суцвіть на особину.

Цікавими на Черемському болоті виявилися знахідки орхідних. Першим об'єктом спостережень стала Hammarbya paludosa (L.) O. Kuntze (Orchidaceae) - представник монотипного роду, євразійський вид на південній межі поширення, що скорочує свій apeaл, індикатор збереженості боліт 3 охоронним статусом зникаючий (Didukh, 2009, s. 186), багаторічна трав'яна рослина, гемікриптофіт, криптофіт, гігрофіт, мезооліготроф, геліофіт. Популяційний локус цього виду займає невелику площу $16 \mathrm{~m}^{2} \mathrm{y}$ складі мезооліготрофного болотного комплексу 3 переважанням дрібних осок i щільного сфагнового покриття. На цій ділянці виявлено 13 генеративних особин середнього та низького рівнів життєвості (рис. 3). Висота пагона коливалася в межах 13,1-23,7 см із кількістю 
Моніторинг популяиій раритетних видів судинних рослин

Черемського природного заповідника (Західне Полісся, Украӥна)

квіток 8-12. Особини перебували в стадії плодоношення, ефективність зав'язування плодів досягала $75 \%$. Просторова структура групова, що вказує на переважаюче вегетативне розмноження ценопопуляції (за допомогою бульбочок, розміщуються на краях листків). Проведений нами аналіз вказує на стабільний стан цієї локальної ценопопуляції, яка неодмінно потребує подальшого спостереження задля виявлення динамічних змін, зокрема пов'язаних із її віковою структурою.

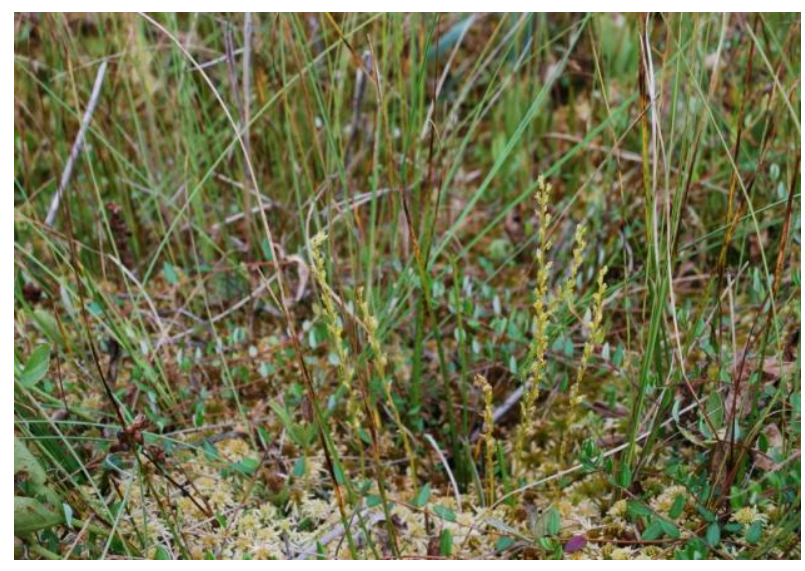

\section{Рис. 3. Цінна знахідка-Hammarbya paludosa (фото I. М. Данилика)}

Інший досліджений вид із родини Orchidaceae, Dactylorhiza incarnata (L.) Soó s.l. євразійський поліморфний вид, представлений численними відмінами, з охоронним статусом вразливий (Didukh, 2009, s. 168), багаторічна трав'яна рослина, коренебульбовий геофіт, мезогігрофіт, мезотроф, геліофіт. На території масиву трапляється доволі спорадично. Площа популяції досягає $5000 \mathrm{~m}^{2}$ із розсіяно-дифузним просторовим розміщенням: поодинокі особини розкидані на віддалі від 10 м і більше одна від одної. На площі 400 м $^{2}$ виявлено лише п'ять генеративних особин на мезотрофній ділянці болота в заростях Ph. australis. Проведено виміри найваріабельніших морфометричних параметрів особин як індикаторів їх віталітету, a саме: висоти пагона, довжини листка та суцвіття. Нижче подаємо отримані дані для цих особин: 1) $\mathrm{h}_{\text {паг. }}=58,5 \pm 2,3 \mathrm{~cm} ; \quad \mathrm{L}_{\text {лис. }}=$ $\left.16,5 \pm 0,8 \mathrm{~cm} ; \quad \mathrm{L}_{\text {суцв. }}=14,3 \pm 0,6 \mathrm{~cm} ; 2\right) \mathrm{h}_{\text {паг. }}=$ $40,0 \pm 1,2 \mathrm{~cm} ; \quad \mathrm{L}_{\text {лис. }}=13,6 \pm 0,6 \mathrm{~cm} ; \quad \mathrm{L}_{\text {суцв. }}=$ $6,7 \pm 0,3 \mathrm{~cm} ; \quad 3) \quad \mathrm{h}_{\text {паг. }}=44,2 \pm 1,4 \mathrm{~cm} ; \quad \mathrm{L}_{\text {лис. }}=$ $\left.17,4 \pm 0,8 \mathrm{~cm} ; \quad \mathrm{L}_{\text {суцв. }}=11,9 \pm 0,3 \mathrm{~cm} ; 4\right) \mathrm{h}_{\text {паг. }}=$ $51,6 \pm 1,5 \mathrm{~cm} ; \quad \mathrm{L}_{\text {лис. }}=19,1 \pm 0,7 \mathrm{~cm} ; \quad \mathrm{L}_{\text {суцв. }}=$ $12,3 \pm 0,5 \mathrm{~cm} ; 5) \quad \mathrm{h}_{\text {паг. }}=39,2 \pm 1,6 \mathrm{~cm} ; \quad \mathrm{L}_{\text {лис. }}=$ $13,7 \pm 0,6$ см; $\mathrm{L}_{\text {суцв. }}=9,1 \pm 0,4$ см. 3 огляду на обліковані показники, особини D. incarnata належать до високого класу життєвості, хоча їх щільність досить низька (0,01 особин на м²). Слід зазначити, що порівняно невисокі показники щільності D. incarnata, як і інших болотних видів, зокрема C. chordorrhiza, Utricularia intermedia, можуть бути зумовлені зменшенням рівня обводнення болота, порівняно 3 попередніми роками. Зазначені види 3 поміж інших $є$ особливо чутливими навіть до незначних змін гідрорежиму, тому їх кількісні показники можуть суттєво зменшуватись. Загалом стан дослідженої локальної популяції наразі не $є$ критичним, проте викликає занепокоєння низька частота трапляння цього виду. Відтак доцільними $є$ проведення подальших спостережень із фіксацією ключових кількісних (площа локусів, загальна кількість і щільність особин) та якісних показників популяції (віталітет особин, зміни у віковій структурі тощо).

\section{Обговорення}

Обрані види рослин відображають різноманітні біоморфологічні типи (моно- та поліцентричний), відрізняються за природоохоронним статусом (зникаючі, вразливі, регіонально рідкісні), участю в ценозах та зазнають впливу як природних змін, так i частково антропогенних навантажень (у разі несанкціонованого порушення норм заповідного режиму), а тому є перспективними як модельні об'єкти в контексті отримання інформативних даних стосовно використання популяційних параметрів під час ведення моніторингу раритетного фітогенофонду. Проведені дослідження властивостей популяцій восьми модельних видів рослин на території Черемського ПЗ дали підставу виявити основні фактори загроз їx існуванню, як природні (ценотичні, едафічні, кліматичні, орографічні), так i антропічні (рекреація, витоптування, руйнування оселищ популяцій, випас тощо). Установлено, що до основних факторів, що негативно впливають на популяційну організацію видів, приурочених до болотних екотопів (Carex chordorrhiza, Carex limosa, Dactylorhiza incarnata, Drosera rotundifolia, Hammarbya paludosa, Salix lapponum, Scheuchzeria palustris), належать зміна гідрологічного режиму, що супроводжується зменшенням рівня обводнення та залісненням території, зміна освітлення й низки інших екологічних параметрів; антропогенне навантаження у вигляді витоптування тощо. В умовах заповідання доцільне здійснення 
контролю демутаційних процесів і підтримання оптимального режиму зволоження на відповідних ділянках болота, що особливо важливо для гігрофільних видів. Позитивний вплив матиме також періодичне викошування як чинник, що перешкоджає процесу сильватизації території, а також стимулює інтенсивне поновлення в популяціях, у результаті зменшення міжвидової конкуренції.

Для видів-гідрофітів (Utricularia intermedia), що відзначаються вузькою екологічною амплітудою, лімітаційним фактором поширення $\epsilon$ відсутність придатних для існування екотопів, а основною загрозою існування - меліоративні роботи (осушення прилеглих до водойм територій), забруднення води й критичне пониження іiі рівня. Тому природоохоронні заходи повинні грунтуватися, передусім, на збереженні їхніх природних типів оселищ.

Відповідно до отриманих результатів щодо структури популяцій вищезазначених видів, аналізу низки традиційних і сучасних популяційних підходів (Harvey, 1985; Zaugolnova et al., 1987; Malynovskyj, 1998; Gibson, 2002; Zhylyaev, 2005; Zlobin, 2009; Dmytrakh, 2013; Zlobin et al., 2013; Kyjak, 2013; тощо), а також на підставі власних досліджень, проведених на території об'єктів ПЗФ (Borsukevych, Izmestieva, Danylyk, 2012; Izmestieva, Danylyk, Borsukevych, 2013; Sosnovska, Danylyk, 2018) уважаємо за доцільне для покращення організаційних засад природоохоронної діяльності на території Черемського ПЗ й ефективного ведення моніторингу залучити низку популяційних параметрів і застосувати відповідні методологічні підходи.

Облік основних структурно-функціональних параметрів слід проводити на конкретних стаціонарних ділянках, які будуть головним джерелом інформації щодо організації популяцій. Розмір трансект залежить як від морфобіологічних особливостей об'єктів, так і від характеру екотопу. Якщо популяція нечисленна та займає малу площу, то достатньою для дослідження $є$ одна пробна ділянка (наприклад для видів Hammarbya paludosa, Salix lapponum, Utricularia intermedia). Якщо ж межі популяції визначити важко через пї протяжність, а екологоценотичні умови $є$ неоднорідними в основній i периферійній частинах популяційного поля, то доцільне закладання кількох трансект (наприклад для видів Dactylorhiza incarnata, Drosera rotundifolia, Scheuchzeria palustris тощо). Для отримання достовірних даних щодо стану досліджених популяцій залежно від просторового розподілу особин i частоти їх трапляння доцільно закладати трансекти площею не менше ніж $10 \mathrm{~m}^{2}$ у межах чітко виокремлених ценопопуляційних локусів. Для отримання достовірних даних за умов мінімізації негативного впливу на популяцію видів (витоптування ділянок) доцільно використовувати облікові квадрати площею $\mathrm{S}=0,25 \mathrm{~m}^{2}$ у межах закладеної трансекти. Детальні дослідження (підрахунок вегетативних пагонів, проростків, тощо) варто проводити на облікових площадках меншого розміру - $S=20(25) \times 20(25) \mathrm{cm}$. Якщо є така необхідність, то можна замінювати облікові площадки в межах популяції для запобігання пошкодженню особин, які існують навколо пробних площ.

Доцільне $є$ проведення фітоценотичних описів пробних ділянок насамперед із метою оцінки проективного покриття досліджуваного виду та його конкурентоспроможності. Вибір облікових одиниць залежить від типу біоморфи дослідженого виду. Для поліцентричних видів варто використовувати рамети (парціальні пагони), у моноцентричних видів об'єми рамет і генет збігаються.

Для проведення детальних досліджень у рамках моніторингу за станом популяцій необхідний облік таких параметрів: 1) диференційні параметри індивідуального рівня (поліваріантність онтогенезу, життєвий (віталітетний) стан, ознаки генеративних особин (висота стебла, довжина листка, кількість квіток, тощо), віковий стан особин, статеві відмінності, репродуктивна здатність генеративного й вегетативного розмноження); 2) диференційні параметри популяційного рівня (щільність i чисельність, просторова структура, вікова структура, статева структура, віталітетна структура). Також застосовують метод розрахунку життєвості популяцій, запропонований для рідкісних видів - індекс віталітету (IVC) (Ishbirdin et al., 2005).

Вищенаведений перелік параметрів індивідуального й групового рівнів, можна застосовувати як для експрес-оцінки, так і для довготривалих моніторингових досліджень 3 огляду на їх інформативність і застосування 3 мінімальним негативним впливом на досліджені раритетні об’єкти.

\section{Висновки}

На підставі проведених досліджень здійснено оцінку стану популяцій восьми 
Моніторинг популяиій раритетних видів судинних рослин

Черемського природного заповідника (Західне Полісся, Украӥна)

рідкісних і зникаючих видів судинних рослин різних рівнів охорони (міжнародного, національного та регіонального) за структурнофункці-ональними параметрами на території водно-болотного флороценокомплексу Черемського ПЗ. На популяціях модельних видів рослин проведено апробацію інформативності диференційних й інтегральних ознак популяцій, які доцільно вибрати за критерії визначення їхнього стану в процесі проведення моніторингових досліджень. Узагальнено отримані результати й розроблено практичні рекомендації щодо застосування пропонованих методик дослідження обраних критеріїв стану популяцій раритетних видів рослин під час їх моніторингу на території Черемського ПЗ, що $\epsilon$ основою науково обгрунтованих критеріїв созологічного менеджменту.

\section{Література}

1. Borsukevych, L.; Izmestieva, S.; Danylyk, I. Information population parameters for management of rare bog species (Rivne Natural Reserve, Ukraine). The 8th European Conference on Ecological Restoration: Programme and Abstract Book (September 9-14, 2012, České Budějovice). 2012, pp 108-109.

2. Gibson, D. J. Methods in comparative plant population ecology. Oxford Univ. Press: New York, $2002 ; 344 \mathrm{p}$.

3. Harvey, J. I., Population biology and conservation of rare plant species. J. White (ed.). Studies on Plant Demography; a Festscrift for John. L. Harper. Academic Press: London, 1985, pp 111-123.

4. Perzanowska, J. (red.). Monitoring gatunków roślin [Monitoring of plant species]. Przewodnik metodyczny. Część 1. GIOŚ: Warszawa, 2010, 256 p.

5. Sosnovska, S.; Danylyk, I. Scientific foundations of monitoring of rare mire plant species populations in protected areas (the case study of Cheremskyi Nature Reserve). The Plant Kingdom in the Red Data Book of Ukraine: Implementing the Global Strategy for Plant Conservation. Proceedings of the 5th International Conference (25-28 June 2018, Kherson, Ukraine). Publishing house Vyshemyrskyi V. S.; Kherson, 2018, p 14-17.

6. Андрієнко, Т. Л. Scheuchzeria palustris L. на Україні. Украӥнський ботанічний журнал, 1975, 32(5), c 617-623.

7. Андрієнко, Т. Л. (заг. ред). Фіторізноманіття Украӥнського Полісся та його охорона. Фітосоціоцентр: Київ, 2006; 316 с.

8. Андрієнко, Т. Л.; Перегрим, М. М. (уклад). Волинська область. Офіційні переліки регіонально рідкісних рослин адміністративних територій України; Дов. вид. Альтерпрес: Київ, 2012, с 9-10.

9. Андрієнко, Т. Л.; Прядко, О. І. Поширення і еколого-ценотичні особливості Carex dioica L. та
C. chordorrhiza Ehrh. на Україні. Украӥнський ботанічний журнал; 1980, 37(3), с 7-10.

10. Голубець, М. А. Екосистемологія. Поллі: Львів. 2000, 315 с.

11. Дідух, Я. П. (ред.) Червона книга Украӥни. Рослинний світ. Глобалконсалт: Київ, 2009; 900 с.

12. Дідух, Я. П.; Шеляг-Сосонко Ю. Р. Геоботанічне районування України та суміжних територій. Украӥнський ботанічний журнал; 2003, 60(1), c 6-17, (in Ukrainian).

13. Дмитрах, Р. І. Завдання і методи досліджень статевої диференціації популяцій трав'яних видів рослин. Наукові основи збереження біотичної різноманітності; Львів, 2013. 4(11), 1, с 21-28.

14. Жиляев, Г. Г. Жизнеспособность популяций растений; Ин-т экологии Карпат: Львов, 2005, 304 с

15. Заугольнова, Л. Б.; Денисова, Л. В.; Никитина, С. В. Программа и методика наблюдений за популяииями видов растений Красной книги СССР; Агропром: Москва, 1987, 34 с.

16. Злобин, Ю. А. Популяционная экология растений: современное состояние, точки роста; Университет. кн.: Сумы, 2009, 263 с.

17. Злобин, Ю. А.; Скляр, В. Г.; Клименко, А. А. Популячии редких видов растений: теоретические основы и методика изучения; Университет. кн.: Сумы, 2013, 439 с.

18. Ізмест'єва, С. В.; Данилик, І. М.; Борсукевич, Л. М. Оцінка стану популяцій рідкісних видів рослин на території торфово-болотного масиву Переброди (Рівненський природний заповідник). Заповідна справа в Україні; 2013, 19(1), с 34-37.

19. Ишбирдин, А. Р.; Ишмуратова, М. М.; Жирнова, Т. В. Стратегии жизни ценопопуляции на территории Башкирского государственного заповедника. Вестник Нижегородского университета. Серия биологическая; 2005, 1, с 85-98, (in Russian).

20. Карпюк, 3. К.; Фесюк В. О.; Антипюк О. В. (упорядн.). Природно-заповідний фонд Волинської області: альбом-каталог; Луцьк, 2018, с 86-87.

21. Кияк, В. Г. Малі популящії рідкісних видів рослин високогір'я Українських Карпат. Ліга-Прес: Львів. 2013, 248 с.

22. Коніщук, В. В. Рідкісні види рослин Черемського природного заповідника. Український ботанічний журнал; 2003, 60(3), с 264-272.

23. Коцун, Л. О.; Романюк, Н. 3.; Кузьмішина, I. І.; Врублевська; С. І., Рало, В. М.; Безсмертна, О. О.; Войтюк, В. П.; Шклярук, Л. В. Список судинних рослин флори Волинського Полісся. Природа Західного Полісся $і$ прилеглих територій: зб. наук. праць Вежа: Луцьк. 2006, 3, с 170-211.

24. Літопис природи Черемського природного заповідника. Маневичі. 2017, 15, 171 с.

25. Малиновський, К. А. (ред.) Структура популяцій рідкісних видів флори Карпат. Наук. думка: Київ. 1998, 173 с.

26. Царик, Й. В., Царик, І. Й. Пошук біомаркерів стану екосистем. Вісник Львів. ун-ту. Серія біологічна; 2008, 46, с 78-82. 